\title{
An Analysis of Anglo-Saxon Kinship During the Middle Ages
}

\section{Joyce Hung}

Prior to their mass invasion and subsequent migration into Britain, the Anglo-Saxons depended on customs and unwritten laws to govern their actions. Their barbaric overlords had no legal or social obligation to bring about justice; therefore, family took on the role of achieving justice if one of their own was wronged. Despite the endearing display of loyalty however, violent blood feuds ensued thereby multiplying the number of issues from the start. In the establishment of Anglo-Saxon jurisdiction in Roman lands and the institution of its first king, the creation of formally codified laws attempting to suppress the vengeful actions of the kinsmen by establishing the court system and due process of law - inadvertently enforced the role and duties of the kin ("Lecture 2: Introduction to the Anglo-Saxons"). This paper explores the relational, social, and legal intricacies of kinship and attempts to depict the significance of kinship roles and duties in historical Anglo-Saxon society.

The first substantial observation which can be made concerns the social significance of the kindred in Anglo-Saxon society. The kindred was a web of manifold, intricate blood and 'bylaw' relationships whereupon marriages were an expansion of family emphasizing on the "collective and relational nature of affinal ties," and everyone else within the family shared a tightknit relation regardless of the distance in familiarity (Pfeffer 124).

Georg Pfeffer exemplified this concept by indicating that an entire lingual system (see figure 1) existed to distinguish the exact genealogical relations of a certain kin, including titles to ascertain their identity in the family (115). Indeed, apart from the immediate relationship between father, mother, daughter and son, this complex system consisted of bilateral categories 
detailing the exact relationship of kin extending further than just the nuclear family. Lorraine Lancaster additionally concluded that these specifications in the exact degrees of relationship "[suggested] that these kin and the distinctions between them [were] not regularly of major significance" ("Kinship in Anglo-Saxon Society: II" 372).

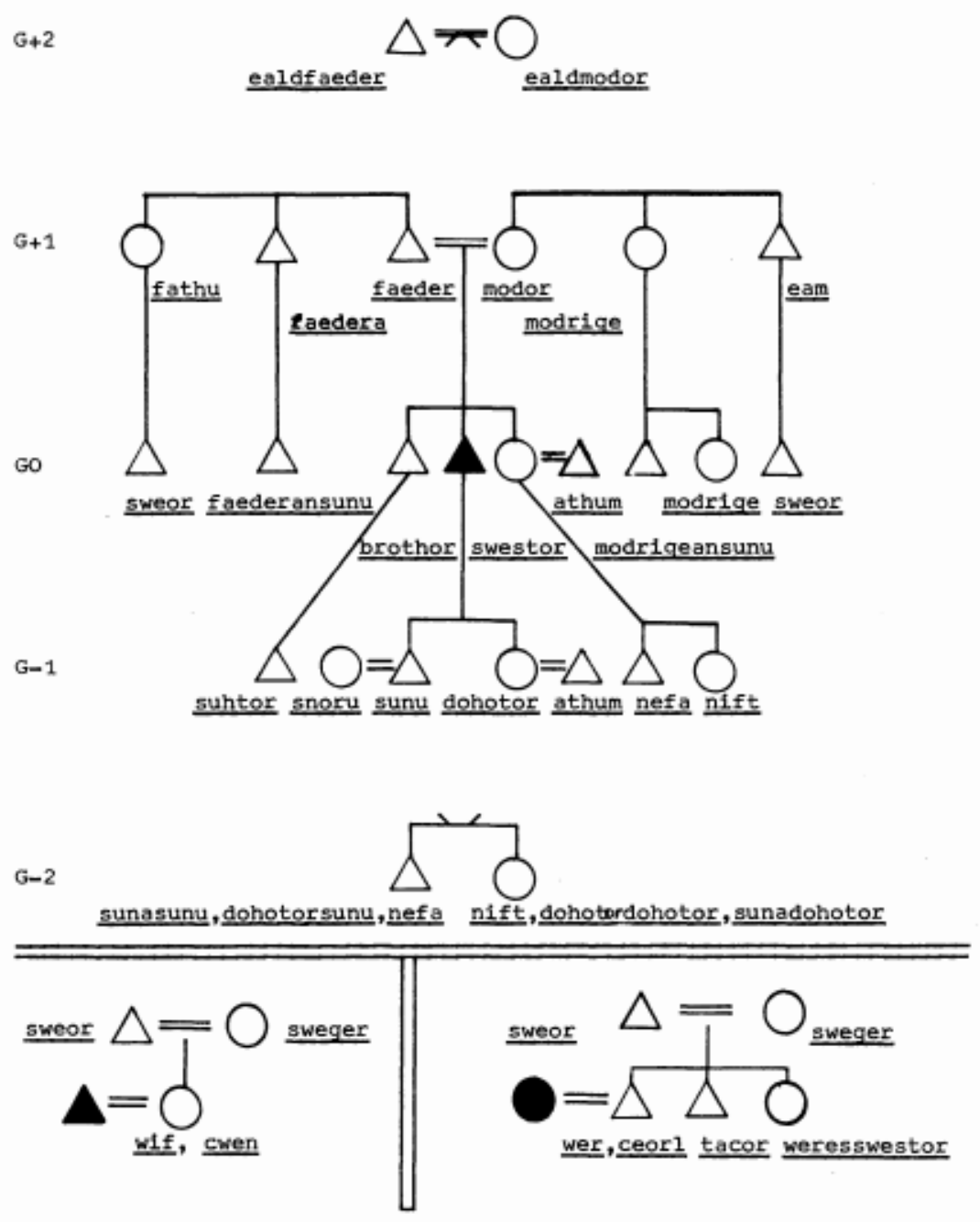

Fig. 1. Genealogical presentation of Anglo-Saxon terms.

This leads to the second major observation concerning family and the importance of collective reputation. While the original concept of blood feuds - or strife between two 
households - stemmed from the conception of repaying "blood [...] with blood" (Rosenthal 139), the newly refined and established Anglo-Saxon society sought to resolve this primitive method of justice. Joel T. Rosenthal attributed Anglo-Saxon's remedy to ending the violence in blood feuds as the propelling force of the institution of the wergild system, or "the composition of personal wrongs through the payment of fines in cash" (139), in which all fines corresponded with the degree of inflicted injury that were made payable to the victim or his family. The subsequent establishment of early medieval laws (or 'dooms') concerned wergild rates, details in wergild payments and their collections in order to bring the kingdom peace.

In the case of murder, as compensation was of no use to the dead, the offender paid the wergild (of a commoner, 100 shillings; of a nobleman, 300 shillings (Hutter 6) to the remaining kin of the victim. Moreover the laws that regulated wergild compensation ensured that in the event of refusal to pay, the offender would be outlawed and the responsibility of partial compensation would fall to his kinsmen. The following excerpt written by Alfred of Wessex illustrates an example of wergild compensation in specified circumstances:

If a man, kinless of paternal relatives, fight and slay a man, and then if he have maternal relatives, let them pay a third of the 'wer;' his guildbrethren a third part; for a third let him flee. If he have no maternal relatives, let his guild-brethren pay half, for half let him flee. (Cap. 29)

The importance of a kin's duty to pay and collect wergild can be traced to the social emphasis on upholding individual and collective reputation in historical Anglo-Saxon society. For the purpose of the kindred's collective identity, this paper will focus on the importance of collective reputation.

Dr. David Rolph accredited part of the importance of maintaining one's reputation as an issue of property and honour (19). Rolph cites Robert C. Post's description of reputation as one's goodwill or credibility earned through "'the exertion of talent' or 'mechanical skill and 
ingenuity" (20), therefore making reputation one's 'property'. Essentially, defaming one's reputation is comparable to destroying one's hard-earned material good; and therefore is under legal protection, just as one's personal property is legally sanctioned from theft or damage. "Reputation as honour" refers to the inherent and attributed "right [attached] to a social role" which can be lost but not gained (24). An example of losing one's honour included receiving verbal or physical insults without the promise of returning even-handed retaliation.

In relation, the payment of wergild was the restoration of one's damaged family reputation, as instigated by the criminal offence conducted by one of their own, in regards to Rolph's definition of reputation as property. Collection of wergild is the maintenance of family reputation in relation to honour through exacting justice, or retaliating, using monetary penalties as retribution. Therefore, the payment and collection of wergild was a critical duty of the kinsmen in Anglo-Saxon society as it contributed to the preservation of family reputation, or as Rolph concluded property and honour.

Another significant duty of the kinsmen, as indicated by Lancaster, is the Anglo-Saxon custom of oath-helping in the court procedure. ("Kinship in Anglo-Saxon Society: II" 370) Oathhelping was the act of character referencing during the trial procedure as a way of swaying the balance of probabilities, which weighed the likelihood of the offender's guilt based on his social standing. The early laws of Aethelstan dictated that a "man demanding payment for a slain kinsman shall be supported by three oath givers, two from the paternal and one from the maternal kin" ("Kinship in Anglo-Saxon Society: II" 373). Likewise, the role of the kindred in court was enhanced as the onus was on the kinsmen to support their fellow relative in a lawsuit. Ultimately, without the help of one's kin, it was very difficult to successfully accuse or defend oneself in court. 
Kinship in the middle ages was also vital as they essentially sustained the inheritance and succession of family property within the bloodline. In the case of death, a father's 'bookland' or will of inheritance was dedicated to his kinsmen, including "sons, daughters (and daughters' husbands), sons' sons, sons' daughters, daughters' sons, brothers (and brothers' wives), sisters, brothers' sons, sisters' sons, nieces (niSte brother's dau., sister's dau.), nephews' children, mother, husband's mother, [and the] mother's brother" ("Kinship in Anglo-Saxon Society: II" 363). The extensive list of possible heirs to an estate was endless because of the social and relational familiarity between Anglo-Saxon relation ties. In her analysis of Anglo-Saxon inheritances, Lancaster indicated that kinship and the division of inheritance also extended to that of the "semi-kin, quasi-kin and ritual kin" (“Kinship in Anglo-Saxon Society: II” 363).

Lancaster further observed that while there was a tendency in giving a little more property to sons than to daughters, there was no overall pattern of preference apparent in the process of bequeathals. Inheritances seemed to be divided equitably, and were not distinctly discriminative against a particular gender, age, or even the closeness of blood ties; for example, a brothers' son in comparison to one's own (“Kinship in Anglo-Saxon Society: II" 363).

The final and significant obligation of the Anglo-Saxon kin was the role of guardianship. Unlike today's state interventions such as foster homes, guardianship was solely a family's responsibility in Anglo-Saxon society. Many laws were imposed to detail the accountabilities of a kin in relation to the care of a family relative, including financial support, legal obligations, physical care and even spiritual guidance.

An example of guardianship laws included the works of Hlothere and Eadric, which state that while a widow had the right to care for her child, a paternal kinsman had the responsibility of caring for that child and the inherited property until he/she reached the age of majority, or 
specifically ten years old ("Kinship in Anglo-Saxon Society: I" 241). In the laws of Alfred, in the circumstance whereby an offender was imprisoned for forty day without food, it was the duty of his kinsmen to provide supplements and even pay for his release, or what can be considered as modern day bail (“Kinship in Anglo-Saxon Society: II” 369).

A major liability in Anglo-Saxon society also involved conducting the ceremonious event known as baptism of newborns. Due to their devout religious beliefs and high mortality rate, the Anglo-Saxons participated in a ritual of baptism to ensure that their child would go to heaven in the event of their death. Failure to do so would lead to state confiscation of the parents' material goods in order to penalize their actions for having to damn their child for eternity (Hutter 5).

To reiterate, the kindred was an important aspect of historical Anglo-Saxon society. It was composed of close relationships between extended relatives, regardless of the fact that many were forged by marriage. In relation, the kindred had various obligations to uphold for the sake of family reputation and to avoid social and legal repercussions. These responsibilities include the payment and collection of wergilds, oath-helping, the distribution and inheritance of wealth, as well as other technical details in the financial, physical and even spiritual care for one of their own. In conclusion, apart from mere blood ties, kinship in medieval Anglo-Saxon society far surpasses today's habitual obligation of the infrequent phone call or holiday dinners. The elaborate roles and duties of kinship ultimately reflected the significance of the kin in historical Anglo-Saxon society. 


\section{Works Cited}

Allyson, Jane. "The System of Wergelds in Anglo Saxon England." Humanities 360. Helium, Inc., 14 Aug 2011. Web. 29 Oct 2014. <http://www.humanities360.com/index.php/thesystem-of-wergelds-in-anglo-saxon-england-2-11452/>.

"Anglo-Saxon Law - Extracts From Early Laws of the English.." The Avalon Project. Lillian Goldman Law Library, n.d. Web. 29 Oct 2014.

$<$ http://avalon.law.yale.edu/medieval/saxlaw.asp>.

Hutter, Dan. "Lecture 2: Introduction to the Anglo-Saxons." HIST 236. University of Waterloo. Waterloo-Kitchener. 10 Sep 2014. Lecture.

Hutter, Dan. Case Studies and Conclusions for Anglo-Saxons 3-6. HIST 236. WaterlooKitchener: University of Waterloo, 2014.

Lancaster, Lorraine. "Kinship in Anglo-Saxon Society: II." British Journal of Sociology. 9.4 (1958): 359-377. Web. 2 Nov. 2014. <http://www.jstor.org/stable/587569>.

Lancaster, Lorraine. "Kinship in Anglo-Saxon Society--I." British Journal of Sociology. 9.3 (1958): 230-250. Web. 2 Nov. 2014. < http://www.jstor.org/stable/587017>.

Pfeffer, Georg. "The Vocabulary of Anglo-Saxon Kinship." L'Homme. 27.103 (1987): 113-128. Web. 2 Nov. 2014. < http://www.jstor.org/stable/25132516>.

Rolph, David. Reputation, Celebrity and Defamation Law. England: Ashgate Publishing Ltd., 2008. print.

Rosenthal, Joel T. "Marriage and the Blood Feud in 'Heroic' Europe." British Journal of Sociology. 17.2 (1966): 133-144. Web. 2 Nov. 2014. < http://www.jstor.org/stable/589052>. 